\title{
EFFECT OF VARIABLE DOSES OF CISPLATIN ON MICROANATOMY OF TESTIS IN ALBINO RATS
}

\section{Rabiya Amin ${ }^{1}$, Ubaid Ali ${ }^{* 2}$, Maheen Nazir ${ }^{3}$.}

${ }^{1}$ Senior resident, Department of Anatomy, Dr Chandramma Dayananda Sagar Institute Of Medical Education And Research, Harohalli, Bangalore, Karnataka, India.

${ }^{* 2}$ Department of Urology, Institute of Nephrourology, Bangalore, Karnataka, India.

${ }^{3}$ Senior Resident, Department of Anatomy, Govt Medical college Srinagar, India.

\section{ABSTRACT}

Cisplatin is an organic metal co-ordination complex andis a widely used chemotherapeutic agent against a variety of malignant tumors, like sarcomas and carcinomas. It interferes with the DNA synthesis and causes apoptosis in view of the fact that the growth of normal cells is also affected. These toxic effects alter the metabolic function of certain tissues and organs. .60 albino rats weighing on an average 100 grams were taken. The animals were divided into three groups. Group A animals received no drug. Group B was injected with $1.3 \mathrm{mg} /$ $\mathrm{m}^{2}$ of cisplatin by intraperitoneal route and group $C$ received $2.5 \mathrm{mg} / \mathrm{m}^{2}$ of cisplatin. The process of drug administration was continued for 12 weeks. The animals were sacrificed in five sittings, after interval of 1,3,6,9 and 12 weeks after drug administration. At the termination of experiments the testis were fixed and stained with $\mathrm{H} \& \mathrm{E}$. There was degeneration of germ cells with increase in capsular wall thickness of testis, and leydigcell depletion and sertoli cell depletion in seminiferous tubules.All these findings were prominent in high dose group and progressively increased in severity.Besides this, there was loss of spermatozoa in the lumen of seminiferous tubules in both high and low dose group ,but was profound in high dose group at $12^{\text {th }}$ week. Though cisplatin effectively treats cancer, at an increased dose it has toxic effects to the genitourinary system and other parts of the body.

KEY WORDS: Cisplatin, Rat, Testis, Chemotherapeutic agent, Apoptosis, DNA synthesis

Corresponding Author: Dr Ubaid Ali, Department of Urology, Institute of Nephrourology, Bangalore, Karnataka, India. Phone number-7006560089 E-Mail: dr.ubaidali22@gmail.com

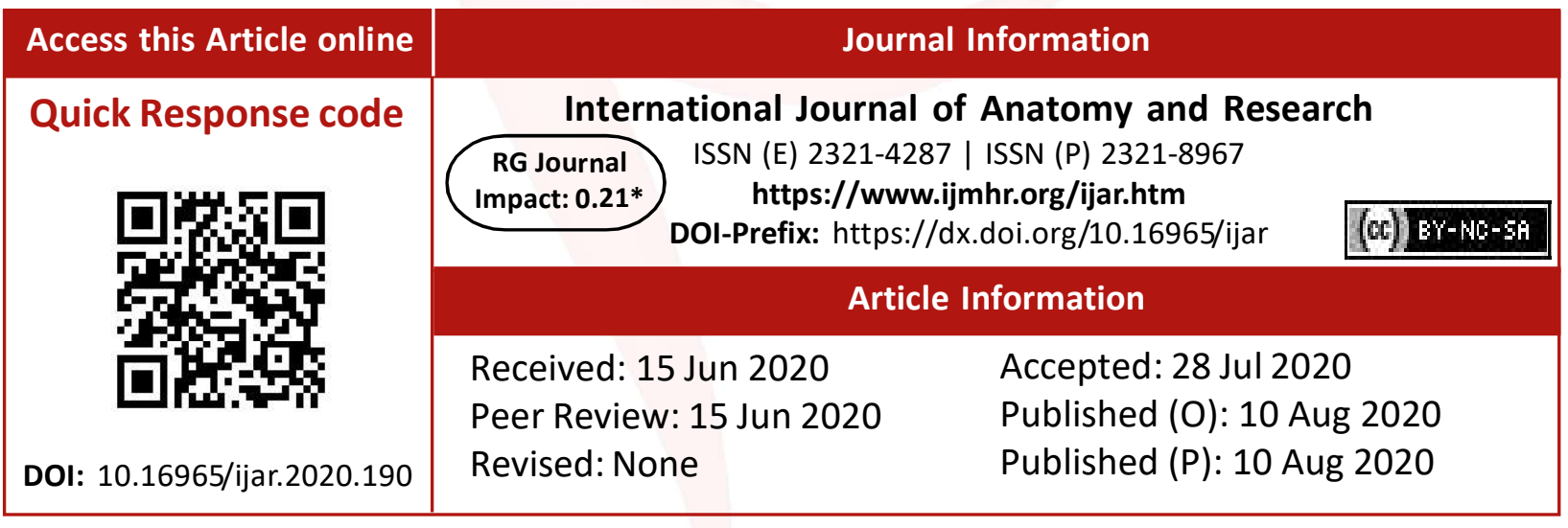

\section{INTRODUCTION}

Cisplatin was created by Michele Peyrone in 1844 and it was known as Peyrone's Salt or Peyrone's Chloride for a long time [1]. Cisplatin is a potent chemotherapeutic agent widely used for cancer treatment $[2,3]$. Cisplatin interferes with DNA replication, which kills the fastest proliferating cells, which in theory are carcinogenic $[4,5]$. The damaged DNA elicits DNA repair mechanisms, which causes cell cycle arrest in the G2-phase and then induces programmed cell death called as apoptosis [6]. Cisplatin is a cornerstone for the treatment of multiple cancers, including sarcomas, some carcinomas e.g. small cell cancer, squamous cell carcinoma of head and neck and ovarian cancer, lymphomas, bladder cancer, cervical cancer and germ cell tumors [2,3]. Cisplatin toxicities are common with higher doses which include Renal and neuropathic toxicities [7-10]. Cisplatin also seems to inhibit Leydig cell testosterone secretion [11] and usual changes in 
hormonal levels observed duringcisplatin treatment may be related to Leydig cell damage [12].

\section{MATERIALS AND METHODS}

The present randomised controlled trial (RCT) was conducted in the Postgraduate Department of Anatomy, Government Medical College Srinagar. Sixty male albino rats weighing on an average $100 \mathrm{gms}(0.1 \mathrm{~kg})$ were taken for the present study. The animals (rats) were obtained from animal house Govt medical college Srinagar. This study was conducted following the guidelines of the Animal Ethical committee, Government Medical College Srinagar. Animals were divided into three groups. Group A (control group) contain twenty (20) rats. These rats were fed normal diet which include grains, vegetables and tap water. Group B (low dose group) contain twenty (20) rats. This group was given low dose of cisplatin at the dose of $1.3 \mathrm{mg} /$ $\mathrm{m}^{2}$. The drug was given intraperitoneally. The rats receive normal diet which includes grains, vegetables and tap water. Group $C$ (high dose group) contain twenty rats (20). This group was given high dose of cisplatin at the dose of $2.5 \mathrm{mg} /$ $\mathrm{m}^{2}$ intra peritoneally. The rats were sacrificed in five sittings at 1st week, 3rd week, 6th week, 9th week and 12th week. In each, sitting five rats were sacrificed from each group. After anaesthetizing with chloroform, midline abdominoperineal incision was given.Testes were identified, dissected and cleaned, and were put on blotting paper. The tissues were processed manually for block making and the slides were stained with haematoxyline and eosin under various steps. Then these prepared slides were seen under electronic microscope.

\section{RESULTS AND DISCUSSION}

Macroscopically there was no significant change at any week after drug administration.

\section{PICTURES}

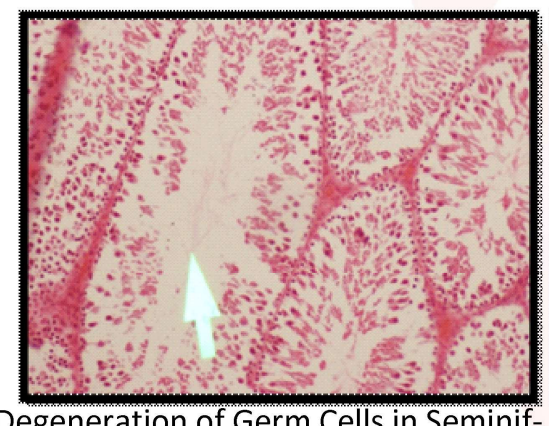

Degeneration of Germ Cells in Seminiferous Tubules Treated with Cisplatin

\section{Microscopic changes:}

Degeneration of germ cells in seminiferous tubules (T.DGS) There was no degeneration of germ cells in seminiferous tubules in control and low dose group at any week after drug administration, however high dose group showed mild change at 3rd and 6th week, moderate at 9th week and severe change at 12 th week.

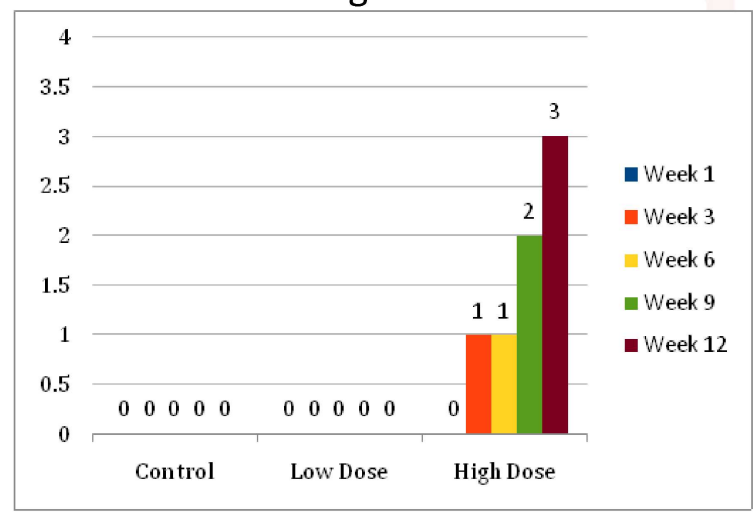

Int J Anat Res 2020, 8(3.2):7703-06. ISSN 2321-4287
Capsular wall thickness of testes: There was no testicular capsular wall thickness in control and low dose group after cisplatin administration, however high dose group showed mild change at $3^{\text {rd }}$ and $6^{\text {th }}$ week, moderate at $9^{\text {th }}$ and severe change at $12^{\text {th }}$ week.

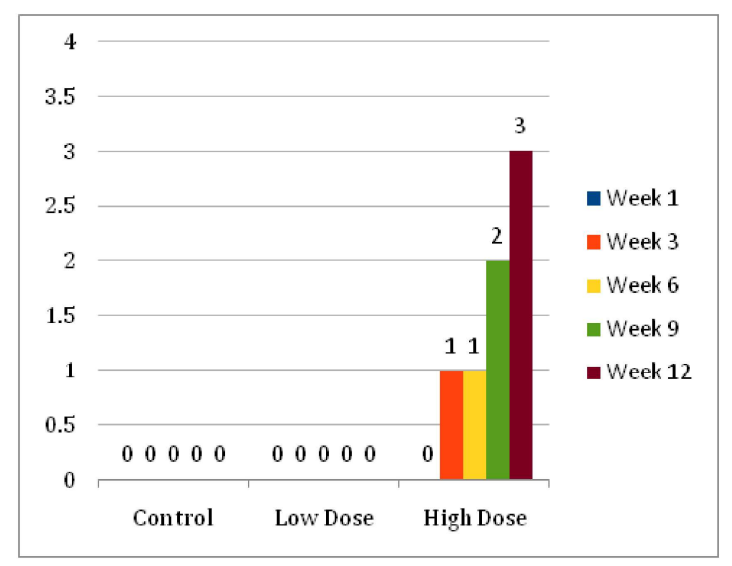


Sertoli cells in seminiferous tubules: There was no change in control group. However, 2 rats in low dose group showed mild decrease in Sertoli cells at $9^{\text {th }}$ week and 2 rats in low dose group showed mild changes at $12^{\text {th }}$ week and 2 rats showed moderate change at $12^{\text {th }}$ week. In high dose group there was moderate change at $9^{\text {th }}$ week in all rats and severe change at $12^{\text {th }}$ week.

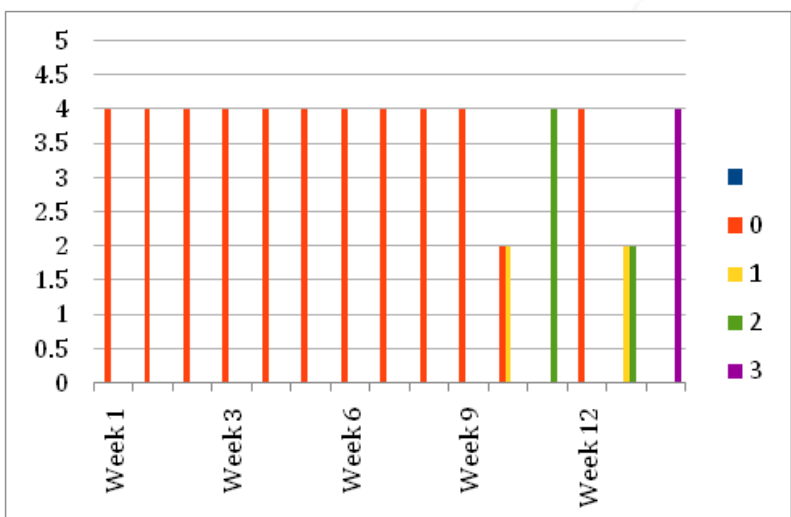

Spermatazoa in lumen: There was no change in control group, however low dose group showed mild decrease in spermatozoa at $12^{\text {th }}$ week and high dose group showed mild decrease at $9^{\text {th }}$ week and severe decrease in spermatozoa at $12^{\text {th }}$ week.

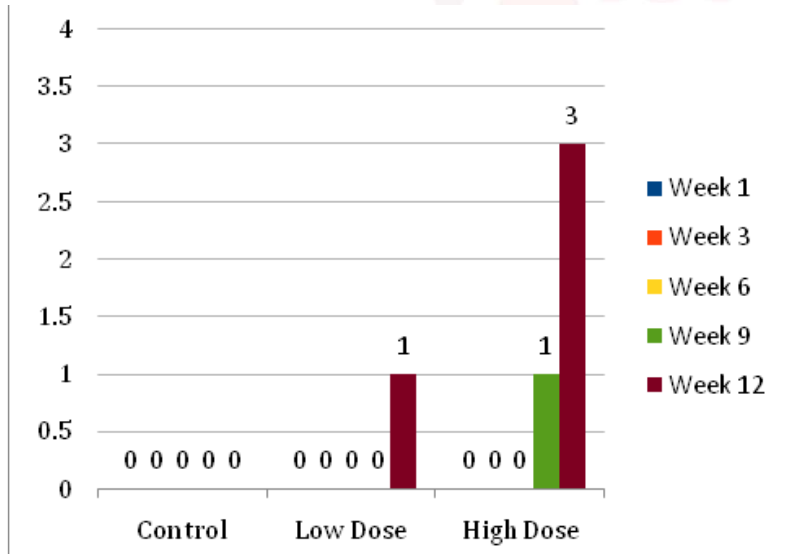

In our study, there was no macroscopic change in the testis after administration of cisplatin, however histologically it was found that there was degeneration of germ cells in seminiferous tubules in high dose group, which started from 3rd week and gradually became severe till 12th week. Capsular wall thickness was prominent and began at 3rd week in high dose group and increased with time. There was leydigand sertoli cell depletion, which was more severe at 12th week in high dose group, however spermatozoa in lumen were severely affected only in high dose group at 12th week. Kadel M et al 2013 [13] while working on effects of cisplatin on testes and chromosomes of rats found similar results. It was found that there was significant reduction of germ cells and sertoli cells. High doses reveal severe atrophy and loss of normal architecture of seminiferous tubules, maturation arrest, cytoplasmic vacuolization and multinucleated giant cell formation.

Hejazi Sajjad 2012 [14] worked on Toxic effect of cisplatin treatment on rat testis tissues, and found similar results. In this study he choose 40 adult male Rats. The Rats were divided randomly into 2 groups as Control and Experimental. Rats of the experimental group were injected Cisplatin in 3 doses $\left(20 \mathrm{mg} / \mathrm{m}^{2} / 5\right.$ days- IP). The control group was injected by normal Saline. Microscopic study showed changeswhich included: diameter of seminiferous tubules and epithelial thickness and the average percentage of tubules with spermatozoa was significant diminished. Testicular atrophy with degeneration of germ cells in seminiferous tubules and testicular capsular wall thickness was prominent. The tubules were shrunken and greatly depleted of germ cells. There were depleted numbers of Leydig cells between the tubules. Sertoli cells with few germ cells were observed in the lumen.

\section{CONCLUSION}

Indubitably cisplatin is a cornerstone for the treatment of multiple cancers. However its significant antitumor action is often limited by the development of toxicity. which is evident in various animal species. When rats were treated with cisplatin, there was degeneration of germ cells in seminiferous tubules, with increase in capsular wall thickness of testis and leydigcell depletion and sertoli cell depletion .All these findings were prominent in high dose group and progressively increased in severity. Besides this, there was loss of spermatozoa in the lumen of seminiferous tubules in both high and low dose group, but was profound in high dose group at $12^{\text {th }}$ week.This has clinical significance, as judicious monitoring of cisplatin is important.This would lead to better compliance and decrease the morbidity of the patients.

\section{ACKNOWLEDGEMENTS}

"Whole Praise is for Allah Who Has Guided Me from Darkness to Enlightenment, To Solace and Contentment" I express my gratitude 
to my husband - Dr Ubaid ali , my son Mohammad Mahir,Dr Martin Lucas, Dr Anisha ,Dr Sangeetha, Dr ShaheenShahdad, without whose help and guidance this study would not have been complete.

\section{Conflicts of Interests: None}

\section{REFERENCES}

[1]. Peyrone, M. Ueber die Einwirkung des Ammonias auf Platinchlorür. [On the action of ammonia on platinum chloride]. Ann. Chem. Pharm. 1844;51(1):129. https://doi.org/10.1002/jlac.18440510102

[2]. Rosenberg, B. In Nucleic Acid-Metal Ion Interactions; Spiro, T.G., Ed.; John Wiley and Sons, Inc.: New York, NY, USA, 1980;1:1-29.

[3]. Desoize B. Madoulet C. Particular aspects of platinum compounds used at present in cancer treatment. Crit. Rev. Oncol. Hematol. 2002;42:317-325. https://doi.org/10.1016/S1040-8428(01)00219-0

[4]. Wang, Dong, Lippard, Stephen J. Cellular processing of platinum anticancer drugs". Nature Reviews Drug Discovery. 2005;4(4):307-320. https://doi.org/ 10.1038/nrd1691 PMid:15789122

[5]. Johnstone TC, Suntharalingam K, Lippard SJ. The next generation of platinum drugs: targeted Pt (II) agents, nanoparticle delivery, and Pt (IV) prodrugs. Chemical reviews. 2016 Mar 9;116(5):343686.https://doi.org/10.1021/acs.chemrev.5b00597 PMid:26865551 PMCid:PMC4792284

[6]. Pruefer FG, Lizarraga F, Maldonado V, MelendezZajgla J. Participation of Omi Htra2 serine-protease activity in the apoptosis induced by cisplatin on SW480 colon cancer cells. Journal of chemotherapy. 2008 Jun 1;20(3):348-54.https://doi.org/10.1179/ joc.2008.20.3.348 PMid:18606591
[7]. Shah N, Dizon D.S. New-generation platinum agents for solid tumors. Future Oncol. 2009;5:33-42. https:/ /doi.org/10.2217/14796694.5.1.33 PMid:19243296

[8]. Günes DA, Florea AM, Splettstoesser F, Büsselberg D. Co-application of arsenic trioxide (As2O3) and cisplatin (CDDP) on human SY-5Y neuroblastoma cells has differential effects on the intracellular calcium concentration ([Ca2+]i) and cytotoxicity. Neurotoxicology 2009;30:194-202.https://doi.org/ 10.1016/j.neuro.2008.12.001 PMid:19118571.

[9]. Flora SJ, Mittal M, Mehta A. Heavy metal induced oxidative stress \& its possible reversal by chelation therapy. Indian Journal of Medical Research. 2008 Oct 1;128(4):501.

[10]. Tsang RY, Al-Fayea T, Au HJ. Cisplatin overdose. Drug safety. 2009 Dec 1;32(12):1109-22. https://doi.org/10.2165/11316640-00000000000000 PMid:19916578

[11]. Vawda Al. Effect of testosterone on cisplatin-induced testicular damage. Arch Androl. Arch Androl1994;32:53-57. https://doi.org/10.3109/ 01485019408987767 PMid:8122937

[12]. Aydiner A, Aytekin Y, Topuz E. Effects of Cisplatin on Testicular Tissue and the Leydig Cell-Pituitary Axis. Oncology 1997;54:74-78.https://doi.org/10.1159/ 000227665 PMid:8978597

[13]. Kadel M, Jha CB, Sangraula $H$ and Bhattacharya SJ. Effects of cisplatin on testes and chromosome of rats: A histological and chromosomal study. J. Pharmacovigilence2013;1:3.

[14]. HejaziSajjad. Toxicity effect of cisplatin - treatment on rat testis tissues. Annals of Biological Research, 2012; 3(5): 2297-2303.

How to cite this article:

Rabiya Amin, Ubaid Ali, Maheen Nazir. EFFECT OF VARIABLE DOSES OF CISPLATIN ON MICROANATOMY OF TESTIS IN ALBINO RATS. Int J Anat Res 2020;8(3.2):7703-7706. DOI: 10.16965/ ijar.2020.190 